\title{
Historical spaces of social psychology
}

\author{
Nikos KALAMPALIKIS, SYLVAIN DELOUVÉE, JEAN-PIERRE PÉTARD*
}

\begin{abstract}
An extensive analysis of all social psychology textbooks published, in french, between 1947 and 2001, including a history chapter, provides a rich corpus for the study of the history of social psychology. In this article we choose to study the historical spaces of social psychology, in order to show how the discipline was located in geographical, urban, institutional and collective spaces. We argue that, into this specific corpus, spaces are essentially related to some solitary and consensual scholars names without any informative reference to their institutions, nor to any trace of collective work. Moreover, we try to highlight several styles, ways and norms of collective writing the history of this discipline.
\end{abstract}

KEYWORDS: history, social psychology, textbooks, scholars, institutions

\section{INTRODUCTION}

Our memories of scientific discoveries are often accompanied by the date and the name of the scientist, sometimes by an image or a formula, and sometimes by an evocation of the setting of the discovery. For example, when we think of the discovery of the DNA code by British scientists James Watson, Francis Crick, Rosalind Franklin and Maurice Wilkins, which marked the beginning of modern genetics 50 years ago, we think of the harmony and complexity of the double helix but we also recall the British ambiance of King's College in Cambridge where the team worked. There are more examples. Marie Curie discovered radium in the Parisian décor of her laboratory, Albert Einstein and his famous formula for the theory of relativity bring forth images in black and white of Berlin and of Princeton, and even when we think of Sigmund Freud, we recall the ambiance of Vienna and psychoanalysis ${ }^{1}$.

We have to make more effort, however, when we think of the birth or of other notable events in scientific disciplines like sociology, anthropology, history or psychology. Names and dates are easily recalled and quickly evoke their origins, but rarely is there a place attached to them. Names and contributions, yes, but not so much where the work was done. On the other hand, names of various schools of thought mark not only a line of ideas but also a place where the scholars associated with them met, worked, thought and published. Think of the Frankfurt School, the Vienna Circle, the Prague School, the Macy Conferences, or even the famous Chicago School. Cities, countries or continents are strong enough first images of place for schools of thought. Obviously, this is not an accident. When a discipline is in search of its precursors (cf. 'the virus of the precursor', Koyré, 1961) and of its theories, some of which have influenced the lives of its students, it must, by definition, have its loci related to its dissemination (or disintegration), i.e., a university locus, and therefore a geographic one.

\footnotetext{
*Nikos Kalampalikis is Assistant Professor in social psychology at the University of Lyon 2 (GRePS EA 4163). SYLVAIN DELOUVÉE is Assistant Professor in social psychology at the University of Rennes 2.

JEAN-PIERRE PÉTARD is a social psychologist associated at the University Paris 7 and publisher of the Bulletin de Psychologie.

The authors are particularly grateful to the Laboratoire Européen de Psychologie sociale in the Maison des sciences de l'homme (LEPS-MSH, Paris) for its assistance with the translation for the article.

Address: University of Lyon 2, Institute of Psychology, 5 avenue P. Mendès-France, 69676 Bron, France [nikos.kalampalikis@univ-lyon2.fr]
} 
In our case, we are interested in a particular discipline in human and social sciences, one that for all practical purposes we know well: social psychology. In a former phase of this research, we sketched out the place of social psychology's history in French language textbooks, published post-war to the present, by showing the periodicity of references to its history, the chronology and the names of scholars mentioned, as well as the transmission from textbook to textbook of certain rhetorical figures and certain recurring 'significant dates' (Pétard, Kalampalikis, Delouvée, 2001).

In this research, the same material was used in order to examine the historical spaces of social psychology ${ }^{2}$. We hereunder mapped them through its own historical references, i.e., its teaching textbooks. Obviously, such mapping cannot be done by itself, neither be limited to locating this or that geographic epicenter on this or that continent. It entails the topography of the convergence of institutions, charismatic personalities, research networks and groups, that is, an institutional and human framework, but also a notional one, since not all social psychologies have the same epistemological foundations nor the same practical aims, and, therefore, not the same history in terms of loci of emergence. This study, as the previous, only discusses the ways of writing the history of the discipline in the textbooks published in the French language since the year when a specific teaching of social psychology was integrated into a newly instituted complete syllabus of psychology.

Here are some of our core questions: Are there specific spaces related to the history of the discipline? The main purpose of this research was precisely to look at how the history of a discipline is written, recounted and disseminated. What rhetorical forms are employed? Which scholars, schools of thought and works are mentioned? Are works on the history of the sciences presented from an epistemological and historical perspective? These, among others, are the questions addressed by this research.

\section{The sample: construction and description}

The material was collected by querying the main data banks and catalogues of libraries, especially academic, with three key words in french: 'social psychology', 'psychosociology' and 'sociopsychology'3 . It is again worth pointing out the elementary nature of these works: their title (Basics, Initiation, Introduction...), purpose (university teaching), and size (one volume, sometimes two) were used as filtering criteria. The period during which these works were published starts with the immediate post-war, which in France was also the time when a specific University degree in psychology was created (1947).

Fifty-three works were selected published between $1946^{4}$ and 2001. Each of them aims to make the field of social psychology and its principal orientations familiar to the reader. However, diversity in the conceptions of the discipline itself as well as in didactic approaches could not be ignored. Respecting the latter, some textbooks offer a collection of excerpts from recent works, while others, more and more rare, have one author presenting the diversity of the most significant works, past and present. This variety in itself constitutes a wealth that students and teachers can discover and make use of.

The provisional choice was made, then, to take into account only the chapters, always at the beginning of the works, that introduce the discipline in the main by references to its history. That they do so is manifest by the title of the chapter itself or quickly comes to light in the text itself. Of the fifty-three works listed, twenty-six present social psychology by way of a history of the discipline (see appendix). At first glance, this practice, or this rhetoric, is relatively stable over the period. Qualitative analysis of the history chapters was done by content analysis while quantitative analysis, given the length of the texts, was done with the aid of a software named 'Prospero',

We will further discuss three key-types of historical spaces of social psychology, i.e., three progressive 'strata' which anchor the references that were analyzed. First of all, we analyze the references to geographic continents, the role and meanings that accompany them, including those to one particular entity, as predominant holistic as it is ambiguous, namely 'America'. Secondly, we look at the place of cities and institutions and at how they are used in historical presentations of social psychology. Finally, we examined the question of spaces - countries, cities, institutions - related to the personalities mentioned in the history chapters as references. 


\section{'AMERICA, AMERICA'...}

Let's first take a look at the distribution of references to continents in our sample from a quantitative point of view. The following graph leaves no doubt that the vast majority of references to the history of social psychology concerns two continents, Europe and North America:

GRAPH 1: Distribution of references to continents in the sample

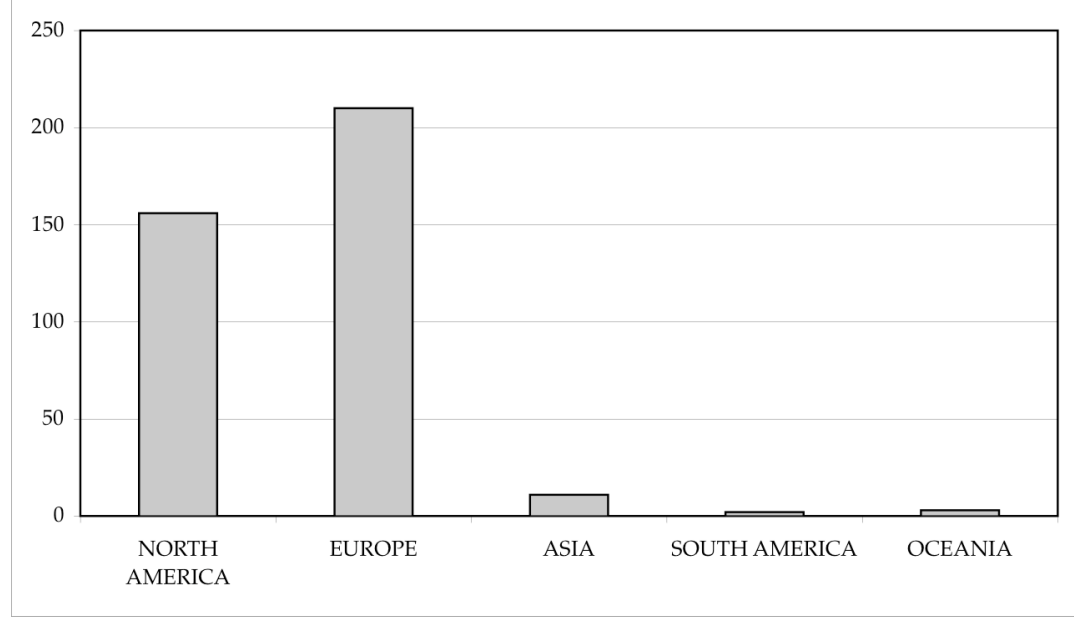

Although it is obvious that references to Europe are more numerous than those to America ${ }^{6}$, it would be hasty to infer that the history of social psychology is fundamentally European. Careful examination of the content of references reveals complications as well as contrasts. Before going into detail, we can see that, in whatever lexical form', 'America' appears as a constant and inevitable point of reference $(80.7 \%)$ in the history chapters of our sample.

This reference appears essentially in the context of five major themes: the organisation of the discipline and that of the related research and universities ('institutionalization'), promotion of research (thanks to public aid and by the intermediary of large studies), specifically American social and community problems, industrial development of this country, and, last but not least, the influx of European social psychologists following the Second World War.

Let's now look at the content of the history chapters. The following quotations shows the main style of references made to the United States (US) in the context of the birth and emergence of social psychology:

$[1954]^{8}$ 'It is in the US that social psychology found the opportunity to become an autonomous science, with powerful means for research, the faith of the public, the teaching faculties and governmental authorities'.

[1977] 'The US is still the country of choice for social psychology. [...] This is how social psychology responded to real needs of different areas of the American society, and as it seemed to be a new science arising in a specifically American context, its prestige was all the more consolidated'.

[1997] 'The development of Social psychology basically took place in the US. [...] It's in the US, between the 20 s and the 40s, that social psychology was established as an autonomous discipline, using the experimental method in its growth'.

The whole references in our sample form 3 important themes which characterize 'America' as it is evoked:

- first, it is presented as a land of sanctuary for European social psychologists trying to escape from the mounting extremism of the thirties in Europe;

- next, it is presented as a land of sanctuary for an entire discipline, i.e., the place where it ultimately established itself, where its first publications and conferences took place, where the first university departments were created, but also the site of innovation for various schools of research (such as behaviourism, the theory of instincts, research on racial prejudice, group dynamics, the new look, etc.); 
- finally, its specific social and economic conditions (i.e., social and community problems, industrial development, etc.) make it appear as a land of predilection for the object of the young discipline.

In light of these quotes, social psychology appears as having a distinctly American physiognomy as far as its social, political and epistemological contexts of birth and emergence are concerned. Nevertheless, our sample highlights that this physiognomy is also quite ambivalent when it comes to its role in the history of social psychology. What underlies this ambivalence is a form of comparison (whether it is explicit or not) between America and Europe and a fortiori between two different histories and two different social psychologies. This comparison sometimes looks as a criticism?.

As far as this comparison is concerned, we have singled out two key issues:

- first of all, the birth of the discipline - whether in terms of archaeology, etymology or instrumentation of ideas - is, mainly situated in Europe, particularly in France and Germany, rather than America. The following few extracts give a glimpse of this underlying antagonism:

[1963] "Whether they want it or not, whether they are aware of it or not, American "social scientists" picked up the main themes of a human science that had developed in Europe and more particularly in France since the 17th century'.

[1968] 'If, in its origins and fundamental developments, social psychology is above all an American discipline, the term itself was used for the first time, almost simultaneously, in Germany and France, as Stoetzel has shown'.

[1993] 'Of Gabriel Tarde, another pioneer, it should first be recalled that he is the creator of the very term social psychology in 1898, ten years before McDougall in the US'.

- secondly, in terms of theoretical presuppositions (loss of interest in theory, ignorance of European scholars, over-generalization of results) and methodologies (experimental versus descriptive approach) of the American social psychology, something of a gap has been created between the present, and in some way, the future of this discipline (although, for our authors, the notion of 'present' depends on the chronology of the publication of textbooks). However, it is at this level that the premises of a form of underlying diachronic critique concerning the American social psychology lie, as it is suggested by the following extracts:

[1986] 'However, given the concrete conditions of the development of this tendency in the US, such an infatuation easily lead to the unilateral development of social psychology; not only did one lose interest in theory, but the very idea of a social psychological theory was to be very much compromised'.

[1999] 'The fact that social psychology is above all American imposes other limitations on the interpretation of results. Subjects from the American population, who participate in experiments, are, quite obviously, not representative of the world population. And yet we know that people of different cultures will not necessarily give the same meaning to identical experimental situations'.

We remind the reader that the most frequently mentioned scholars and the most consensual ones have already been discussed elsewhere ( $c f$. Pétard, Kalampalikis, Delouvée, 2001). Yet, it is quite interesting to consider these results as relevant for our current issue. Among the ten most representative scholars ${ }^{10}$ (mentioned in at least one quarter of the sample that contained a total of approx. 700 names of authors), 6 are Europeans, while among the ten most frequently mentioned scholars ${ }^{11}, 7$ are European. The quantitative perspective on the references to scholars whose works have more or less fundamentally influenced the discipline shows similar results: the majority of references point toward Europe. There is indeed no need to mention the suggestive power of these names, especially when they arise as they do from the history of a discipline, and within a specific literary and academic genre, the textbook, whose target readers are the student population.

Rather than highlighting the signs of an anti-American or, conversely, pro-European sentiment here, we are much more concerned with showing that the history of social psychology, or indeed the history of any discipline, is not immune from the epistemological differences of the present nor the socio-economic variables that have influenced its development in the geographical contexts of its birth and emergence. The 'America-Europe' pairing illustrates this idea of a history and a discipline that is eventually pained by trying to plant both feet firmly on the ground. In light of these results, we get the feeling that eventually each of the two continents will look to become the main owner of the 'borrowing' and make the other the debtor. This tension comes as an echo of recent discussions in the history of social sciences, and notably 
in social psychology, about the heritage and influence of Gordon Allport's chapter (1954) and the attribution of American origins to social psychology ( $f$. Apfelbaum, 1993 ; Farr, 1996; Good, 2000 ; Lubek and Apfelbaum, 2000 ; Lubek, 2000). This question, already explored ( $f$. Cartwright, 1979 ; Collier, Minton and Reynolds, 1991), is re-exposed here in order to be applied to our body of work.

We return now to the guideline questions of this research. We have so far traced a large geographical and historical map of the discipline on two continents, both of them relevant for its past, its present and its future. But what evidence do we have of its urban and institutional record? In which towns and in which institutions of these continents were the developments of social psychology presented and staged?

\section{CITIES AND INSTITUTIONS: CHICAGO OR MIT?}

A number of cities will be recognisable along the way. What role (or roles) do they play in our sample? Are they characterized by a national reference? Are they named in a historical or social context? Are they simply convenient labels? Some seem to be effaced by the prominence of the institutions they accommodate. Others seem to merge with the schools of thought that have come through them.

\section{Chicago: one and many}

The 'Cities' collection, first of all, is made up of a list of cities from all over the world. Ten chapters of the 26 making up our sample do not mention any city. A little less than half, then, chose to write a history of social psychology without any specific setting ${ }^{12}$. It is a matter of history of ideas after all. Science, by definition, knows no frontiers; there is no Tuscan or English law of gravity - although there are different representations of this law. Social psychology seems to be seen here through the lens of 'hard' science, in its search for universal laws independent of any locus of discovery.

Are cities mentioned as reflections of discoveries, inventions and creations? As such, the most frequently mentioned cities are Paris, Chicago, Princeton, Dartmouth and Berlin. A great majority of the other cities mentioned are European but appear only once in a chapter: they are mentioned anecdotally and with little connection to the history of social psychology.

Chicago is the only typical ${ }^{13}$ city in our sample: it is mentioned 9 times in 7 texts. Instead, Paris, though mentioned 23 times, is actually mentioned 20 times by [1999c] in reference to works mentioned in the text rather than grouped at the end of the book or the chapter ${ }^{14}$. Chicago is referred to in 3 distinct ways. Firstly, the name of the city is used as a convenient label for works or for researchers in reference to a school of thought called the 'Chicago School'. Secondly, it is related to the famous research at the Western Electric Company factories (which were actually located in Hawthorne, near Chicago; of. Pétard, Kalampalikis and Delouvée, 2001). Finally, it refers to a (more or less remarkable in the history of social psychology) place or event:

[1980] 'Mayo's first works at Western Electric were barely published when a significant book for Social Psychology came out of Chicago, Mind, Self and Society, by George Herbert Mead.'

[1997] 'And so in 1932 Thurstone came out with the first attitude scales used to measure the opinions of 266 Chicago students on the gravity of several crimes.'

Except for Chicago, the chapters in our sample makes little reference to cities. It appears that the history of social psychology is not rooted in any cities in particular. If this is the case, shall we think that institutions, loci of production and dissemination of knowledge, play a more important a role than a mere geographic place? It is noticed that for some authors the location of prestigious institutions is of secondary importance. Readers are supposed to know or to guess that the New School for Social Research, among other examples, is located in New York City. As previously mentioned, a total or partial homonymy between city and institution appears in these introductory chapters of textbooks. If social psychology and its history are not rooted in any particular cities, will institutions play this role? 


\section{Phantom institutions}

Whereas the 'Cities' collection is made up of a long list of cities related to the 'Institutions' collection, the "Institutions" collection itself was constructed directly from the sample. It is made up of expert societies, teaching establishments (universities and schools), research centers and international organisations. The collection was created by searching the sample directly using various key-words (such as 'university of or 'institute of') and integrating the results into the already existing list of institutions. Similarly to the 'Cities' collection, which only consists of very few representatives, the 'Institutions' collection shows that 9 chapters of the 26 used include no reference to any institution. Among these 9 chapters, 4 do not contain any representative from the 'Cities' collection either ( $c f$. supra). It indeed seems to be a matter of the manner in which history is written here. Authors choose to appeal to cities and institutions for support when writing about the history of social psychology - or they don't. Let's note that the 9 chapters which made no appeal to institutions in their description of the history of social psychology were published between 1954 and 1999. Thus, it seems that this trend is constant over time: in this respect no evolution is noted in the way of writing the history of the discipline. Thus, referring to institutions depends entirely on the authors.

As opposed to these 9 chapters, the other 17 do refer to institutions. The institutions mentioned may be divided into two subsets, of almost equivalent size, according to the continent where they belong: North American $(n=37)$ and European institutions $(n=36)$. More than three quarters $(78.38 \%)$ of North American institutions are university centers as opposed to about $60 \%$ of the European ones. The remaining institutions are expert societies or international organisations ${ }^{15}$. When it comes to the distribution of the 'Institutions' collection, two elements are salient: on one hand, several institutions $(\leq 6)$ are mentioned in almost all the chapters and, on the other, 2 of the chapters refer, respectively, to 35 and 36 references (significantly more than the others).

When the chapters mention only one institution, one could suppose that this unique reference carries a particular importance which the author wishes to stress. Instead, one reads in [1963a]: "It is difficult to judge the state of social psychology in such and such a country, at such and such a time, without establishing a comparison with other disciplines referred to as 'social sciences' ". Let's take a look at the recent history of the science of economics. In 1945-1947 the decisive work of von Neumann and Morgenstern was published in Princeton: Theory of games and economic behaviour [1963a]. Even if the theory of games played an important role in social psychology and allowed much research, the mention of Princeton seems to act as a scientific caution for this book. Moreover, we don't know if this author was not simply referring to the city of Princeton. ${ }^{16}$

By contrast, two scholars make extensive references to institutions ( $\geq 35$ ). Do they write history in a different way? The first of them, [1996], mentions 35 institutions. This chapter is presented in a quite different manner: it uses markers. The targeted readers are students: the markers provide them with synthetic information on major facts, dates and scholars. This scholastic view of history is far from the historical approach and very pragmatic in terms of teaching dates, places, and names of scholars and theories before the exams. For example, in [1996]: 'Jerome Bruner. Professor at Oxford University in Great Britain, then at Harvard, then professor of psychology at the New School for Social Research - his work in the area of social perception and cognition (1991) profoundly influenced the development of the cognitive sciences.'

The informative content regarding institutions is slight, if there at all. There is only a list of universities and research centers and institutions seem to be considered as a mere crossing point: 'institution $\mathrm{X}$ welcomes researcher Y'. It's more like a list of train stations, one after another. In the end, one is left with more questions than answers.

The references made in [1996] may be grouped into three categories: national references, references to institutional affiliations, and, references to Kurt Lewin.

The most numerous references in this chapter, which is part of a Canadian textbook, are made to Canadian universities. This may be explained by the organisation of research and of universities of social psychology in Canada through the creation of professorships. Example: 'Canadian social psychology seems to have taken root mainly in three Anglophone departments, those of McGill University, the University of Toronto and the University of Alberta.' 'The first course in social psychology in French was given in 1942 at the Institut de psychologie (now the psychology department of the Université de 
Montréal).' Secondly, this chapter refers to the scholars' positions within institutions, without further justification or explanation, such as, 'the prestigious Harvard University', for example, now chaired by X or we are told that Y has moved to "Smith College, in Massachusetts" or that "Stanford University" now welcomes Z. Lastly, this chapter mentions 5 institutions related to Kurt Lewin (he is the only researcher with such a number of institutions related to his name): (Institute of Psychology at Berlin University (1), University of Iowa (2), Research Center for Group Dynamics (3), Massachusetts Institute of Technology/MIT (4), University of Michigan (5)). It is also interesting to note that the highest number of occurrences for one institution in our sample (more precisely in the 17 chapters that mentioned an institution) is 8: the "Massachusetts Institute of Technology" is mentioned 8 times in 5 chapters.

More precisely, the reference to the MIT is related to Kurt Lewin and the Research Center for Group Dynamics, which he founded:

[1979] 'At the same time, a Research Center for Group Dynamics, at MIT, was established under the direction of Kurt Lewin.'

[1984] 'Several psychologists see Lewin as the founder of modern social psychology. After fleeing the Nazis in Germany, he founded, in 1945, the Research Center for Group Dynamics, at the Massachusetts Institute of Technology.'

[1996a] 'Kurt Lewin, professor at the Institute of Psychology of Berlin (1924), at the University of Iowa (1935), then founder of the Research Center for Group Dynamics at Massachusetts Institute of Technology (MIT) (1944).'

Finding the date of the creation or founding of a laboratory is always a delicate matter. The act of birth itself is not usually accompanied by a birth certificate and when the laboratory has to move, records always suffer. Science historian must then be careful (cf. Delouvée, 2000) and can only suggest hypotheses supported by existing evidence. Lewin (1945) in an article describing the activities of the center and justifying its affiliation with the MIT, did not give a precise date for its creation. According to Cartwright 'the founding of the Center may be dated as during the academic year 1944-1945, when Kurt Lewin went to the Massachusetts Institute of Technology' even though 'the origination of the idea of such a Center [...] occurred some time before that' (1958: 3). These examples show, then, that it is more a question of inaccuracies than of totally erroneous information.

The numerous references to the Canadian universities of Toronto and McGill are not representative of the whole sample since they all come from the same Canadian textbook [1994]. In turn, the example of Lewin shows us a close association between an institution and a researcher. Yet, from the other examples, it seems that cities and institutions act only as labels. Can it be said, then, that it is only scholars who are of interest?

Let's now look at the relationship between the scholars and the spaces mentioned in our sample countries, cities, institutions - to which they were related, from which they fled or where they worked.

\section{MAJOR SCHOLARS AND THEIR SOLITUDE}

How are scholars - those mentioned in the sample and, therefore, those who have left their mark on the history of social psychology - presented? Are their names related to those of a city, a country or an institution? The textbook reader may hope to discover both the scholars and how their work takes form as a result of their affiliation to such and such institution or expert society, or as a result of where they go and who they encounter. One would also expect to gain a familiarity with events, if not some understanding of them - or at least some clues - surrounding how a school of thought comes about, gains ground, and develops. The above mentioned institutions must have had a life, a mind, adjustments, whether necessary or inspired, involving the same people who have recognisably influenced the development of social psychology. How are these connections, between scholars and institutions, between scholars and cities or countries, shown in the sample? Are their activities described? If so, which ones? 


\section{Those ethereal creatures}

This brings our attention to the typical scholars ${ }^{17}$. For the sake of precision in comparisons, we exclude those who lived in antiquity, up to 1850 ( 9 in total, including Plato and Aristotle), because when their names are mentioned in relationship with geographic locations, this cannot, of course, be compared with the case of the ones who lived after 1850, when the organisation of research and of universities was beginning to develop as we still know it today.

Of the 37 most significant of these scholars, only $16^{18}$ are accompanied by details of a relationship with an organisation, a city or a country. On the other hand, no indication of affiliation with any university, research center, other institution, or a geographic location, is given for the 21 others ${ }^{19}$. When mentioned, the names of these scholars is thus typically only related to the title of a work, to the name of a method or to a theory. This could lead one to believe that these people are pure minds, or perhaps the readers may situate them geographically thanks to their own cultural background.

References which do situate scholars typically focus on their functions and titles in the universities where they work(ed), their moves from one university to another, or from one country to another, as we have indicated already, but rarely emphasize their innovative contributions in relation to place.

[1994] 'Fritz Heider (1896-1991), for one, left Hamburg, in Germany, and went to Smith College, in Massachusetts, until 1947, then to the University of Kansas until the end of his career.'

Sometimes, information is given in order to understand the reason behind a move: [1994] 'Feeling the threat of the looming Second World War, Lewin, who was Jewish, left Germany to join the University of Iowa in 1935.' The large migration from Europe to the US at the time of mounting Nazism is generally very visible in the history of the sciences. In the chapters of our sample, however, it is very rarely expressed.

\section{Professor at the University of...}

If we enlarge our collection of scholars by taking into account not only typical scholars but all those whose name is associated with a geographic location, the same narrative choice is confirmed. The first and largest group shows a simple connection between a scholar and an organisation, that is, his affiliation and, usually, his title $(\mathrm{X}$, professor at $\alpha)$.

[1954a] 'Max Adler, professor at the University of Vienna and Marxist theorist, followed the psychological study of this doctrine.'

[1996a] 'Jean-Paul Codol, professor at the University of Aix-en-Provence, achieved great notoriety, in France as well as abroad, with his work on the PIP effect 1973, 1975.'

Throughout these examples, it is quite clear that the organisation, to which a scholar is affiliated, performs the function of a label only, something like the publisher in a bibliographic reference. The university and the laboratory are presented as places where one teaches or studies. But these are also where innovative research is conceived and notable papers are presented.

[1999c] 'It is prudent, however, to point out that in some work, like that of Muzapher Sherif, in 1935, at the University of (sic) ${ }^{20}$ Columbia, on the creation of standards and attitudes leading to the implementation of systematic and repetitive observation mechanisms, coherent with the plan of a social psychology.'

References frequently underline creation or foundation. Whether our scholars are associated with a university or move from one to another, their actions are somewhat standard; they teach, supervise a laboratory and theses, conduct surveys, publish, initiate studies...In general, a scholar is mentioned for a founding act or, more precisely, a place is indicated because it corresponds to a founding event. It can be a matter of a university: [1954a] 'He [Ross] was the first to hold a chair in social psychology, in 1899, at Stanford University, and to publish in 1908 a work entitled Social Psychology.'; a research center: [1996a] 'Kurt Lewin, professor at the Institute of Psychology of Berlin 1924, at the University of Iowa 1935, then founder of the Research Center for Group Dynamics at the Massachusetts Institute of Technology (MIT) 
1944.'; sometimes, again, a country, without a more specific location: [1996a] 'He [Stoetzel] launched the first opinion poll in France (1938) before founding the Institut français d'opinion publique.'

It is interesting that the emphasis is generally placed on the act of the scholar. The research center or university only appears as the passive locus of reception.

\section{The university, the laboratory, the country: site of reception or just a label?}

In the history of social psychology, people move from one country to another, from one university to another. With the exception of Lewin fleeing the Nazism [1994], no reason is given in an effort to understand why a scholar leaves a country or university or that he finds, apparently without difficulty, a university position. They simply move. There is almost no mention of proactive local or national policies regarding the development of research, of politics of welcoming immigrants fleeing war or conflict, or of any socio-economic or political factors outside the discipline of 'social psychology'. On the other hand, the mention of 'originally from' such a city or country can incite the reader to connect the person's movements with historical events, without always being provided with an explanation.

[1996a] 'Serge Moscovici, French psychosociologist, originally from Romania, taught at several universities (Geneva, Louvain, New York City) and was a member of the Institute for Advanced Study (Princeton) and the Center for Advanced Study in Behavioral Sciences (Stanford).'

This single example demonstrate a characteristic pattern of exposition ( $\mathrm{X}$, originally from country/city/institution). It is consistent with examples from other textbooks mentioned earlier, though in a simplified form. The names of countries, cities and institutions constitute markers, easy to memorize perhaps, but quite useless for questions like 'how?' or 'why?'.

\section{Signs of Collective Work and the Functioning of Institutions}

A richer aspect is related to the collective activities associated with an institution, a city or a country. However, most of the references (see below) to particular methods of professional practice are unique. Nevertheless, it seems useful to emphasize them, by way of contrast, with what does not appear in the associations made by the authors of our sample between the personalities of the history of social psychology and their spaces.

One finds, for example, biographical elements related to the training of a scholar ([1986] 'Kurt Lewin was trained in psychology at the Institute of Psychology at the University of Berlin.'), information about the functioning of institutions, such as elections ([2000] "Halbwachs was elected to the Collège de France in 1941, to a new chair called 'Collective Psychology'.”), or affiliations ([1999c] 'William Isaac Thomas (18631947), known as Albion Small, joined the department of sociology created at the university in this city.', which anticipate their collective and organized work.

People seem to gather in the same place for a founding act ([1996b] "In the first two decades of the century, Max Wertheimer 1880-1943, Kurt Koffka 1886-1941, and Wolfgang Köhler 1887-1967, founded the School of Gestalt Psychology in Berlin, whose name came from the word 'gestalt', meaning 'the shape' in German."), or to expose their innovative ideas at seminars or conferences organized by expert societies. These references to a larger context enrich the information and contrast with the image of the solitary scholar, inventor or proponent.

Lastly, the gathering of scholars from different countries, or research covering more than one country, or more than one period of time, show the internationality of scientific research, but are surprisingly rare: [1974] 'A collection of research which, next to previous work, is devoted to the differential study of racial or national groups: one may mention the research of Otto Klineberg on the differences between racial groups, social classes, national groups, which begun in the US and continues today, in France, in seminars of the École Pratique des Hautes Études.'

In the same sense, references to debate, controversy or polemic, such as advocated in the ideals of research, appear only once when it comes to associations of scholars and spaces: [1979] 'In America, the death blow to this way of explaining social behaviour was delivered by members of the behaviourist 
school of Chicago such as Watson, Kue, Dunlop and Holt. McDougall (1908) saw instincts as broad tendencies and oriented toward individual satisfaction, emerging from the evolutionary process.'

To summarize, when the names of scholars, whether typical or not, who marked the history of social psychology, are associated with spaces (countries, cities or institutions), the latter are considered as mere labels. Rare examples help us to understand (or at least to imagine) that major scholars did not work by themselves, but within structures that were created and brought to life by specific people, that those organisations had their own rules and habits of practice, and that active communities did exist as well (and had the power to accept, appoint, refuse...). The spaces that witnessed these events are mostly universities or research centers, which are only sometimes placed in a city or a country. Other than these rare examples, the norm of writing the history of social psychology seems to be the following: in this place, someone did something for the first time, which is quite the same model that is used on commemorative plaques. The vast majority of scholars, then, are not deprived of organisational affiliations, but the latter simply cannot be discerned by the readers.

This 'way of writing' history suggests that scholars are free from professional and social constraints in the assertive acts of creation and foundation. Personal and collective acts, in contexts that are more or less favourable to them and that condition their outcome, are blurred, if not left out altogether, perhaps ignored or forgotten. Finally, it appears that our founding fathers worked outside of any conflict or controversy, despite the fact that controversy is the engine behind the development of knowledge activities. If all such indications are absent - the functioning of organisations in their cultural, geographical and historical contexts - how is the novice reader to set the scene of scientific activity?

\section{DISCUSSION}

If the ideas themselves are indeed immaterial, their translation in a coherent and relatively autonomous sample, from the epistemological point of view, that is to say a disciplinary field, is much less so. Otherwise, it is necessary to find the geographic and institutional spaces that become the carriers and transmitters of a scientific school, that affirm this or that scholar, this or that theory, but also groups of research, laboratories, support publication, in other words, provide the conditions and the spaces for scientific production and dissemination. These true spaces of the history of a discipline are effaced as the discipline develops and become vague in the light of the present day.

We are interested in a genre of history (that is, a genre particular to scientific discourse) which is found in chapters explicitly devoted to it, in textbooks of the discipline. We have tried to be exhaustive in our study of all social psychology textbooks published in French, post-war to the present. The interest in this type of publication lies in its generally very broad dissemination and in its main target audience, that of students learning the basics of the discipline, and of their teachers. It is also certain that these textbooks are written in a specific style and that they 'serve a professional group as a legitimating compendium or reference or mentoring tool and are therefore inevitably presentist and often celebratory' (Lubek, 2000, p. 321).

The choice of texts for the constitution of our sample is not, of course, exempt from criticism. How are histories of theories, concepts or scholars presented in other chapters of these textbooks where various aspects, fields and themes in the discipline are treated? How do scientific presentations other than those in textbooks, such as review articles or monographs, treat history? Our choice thus has limits and our conclusions bring them along. Nevertheless, our main objective has been to define a collective writing practice of the history of a discipline, inevitably a 'mutualist' practice (Good, 2000, p. 383), that is to say constituted by the academic trajectories of the authors of the different chapters, their sources, the presentation support (textbook), in addition to the tensions linked internally to the object itself (social psychology). This same practice is analyzed as such, variations around a theme (the history of social psychology), without any implicit comparison with another, 'superior' or 'better', and without proposing a 'counter-model'. But when the goal is to find the general shape of a 'model' of writing this history, i.e., the norms of presenting it, a reliable sample had to gather a diversity of works made on this matter (more than 20 different authors). And norms were found.

A quick look at the collection of textbooks is enough to see the place given to, or occupied by, the history of social psychology. About one textbook of every two contains a chapter devoted to the history of the 
discipline, which is always presented in a chronological manner which witnesses a stable, though halfhearted historical interest. By choosing to study historical traces of the discipline in urban, institutional or collective spaces, we discover some 'usual way' of writing it.

First, in regard to continents, we have seen a general trend to relate the history of social psychology to an East-West axis (Europe-America), which appears as a geographic and epistemological axis of tensions and to look to define those responsible (and those culpable) for the history and for the present of this discipline. This dichotomy has produced at least two faces of the discipline and still does.

Next, we must say that major cities and institutions which have contributed to the birth and development of social psychology are almost absent of the sample. Cities are mentioned in as much as they are seats of establishments - university, laboratory, research center, conference location - or of publishers - or a place of where a work was published, whereas institutions appear as the places of reception (of the great men). One presentation of history argued for a conception of scientific work and of science as independent of any geographic, historical, economic, etc. context. Another is constrained by the context of 'the history of social psychology' that implies that there is an object (social psychology), wrongly conceived as a subject of science, independent of any social or historical contingence. The authors of our textbooks may give some thought to Canguilhem (1968): 'The history of science is the history of a subject that is a history, that has a history, whereas science is the science of a subject that is not history, that has no history.' A chronology does not make history.

In the eyes of the authors of our chapters, the highest priority appears to be the names of scholars. Considering their abundance, more than 700 in total, and above all the way in which they are used, the history of social psychology is in its essence a history of scholars, who are very often disconnected from their work places, from their colleagues, from the socio-political conditions in which they worked, published and theorized the psychological and the social. Therefore, the language used to present, imagine, recount, teach and learn the history of social psychology appears to have a distinct style: it is a nominative language. The past of the discipline is called up as an apologetic chronology, a list of names and dates. These two elements together form a very specific genre of writing designed for a particular and limited didactic purpose that may be commonly called a marker. These reading markers correspond to a mnemonic, thus ephemeral, learning system, characterized by a flagrant, yet natural, absence of references to works on the epistemology or history of the sciences. In brief, nominative language prevails over informative language. The historical spaces of social psychology are its own names. 


\section{BIBLIOGRAPHY}

Allport, G.W. (1954) 'The historical background of modern social psychology', in G. Lindzey and E. Aronson (Eds), The Handbook of Social Psychology, vol. 1. Reading: Addison-Wesley, pp. 1-80.

Apfelbaum, E. (1993) 'Quelques leçons d'une histoire de la psychologie sociale', Sociétés Contemporaines, 13 (93): 13-21.

Canguilhem, G. (1968) Études d'histoire et de philosophie des sciences [Studies on history and philosophy of sciences]. Paris: Vrin.

Cartwright, D. (1958) 'Some things learned: An evaluative history of the Research Center for Group Dynamics', Journal of Social Issues, Supplement Series 12: 3-19.

Cartwright, D. (1979). 'Contemporary Social Psychology in Historical Perspective', Social Psychology Quarterly, 42(1), 82-93.

Chateauraynaud, F. (2003) Prospéro - Une technologie littéraire pour les sciences humaines Prospero. A literary technology for human sciences]. Paris: CNRS Editions.

Collier, G., Minton, H. and Reynolds, G. (1991) Currents of thought in American social psychology. New York: Oxford University Press.

Delouvée, S. (2000) Le(s) laboratoire(s) de psychologie sociale de la Sorbonne: la (re)construction de la psychologie sociale française [The social psychology laboratory(-ies) at the Sorbonne: the re-construction of french social psychology]. Unpublished dissertation, Master degree, University René Descartes (Paris 5).

Farr, R.M. (1996) The Roots of Modern Social Psychology (1872-1954). Oxford, Basil Blackwell.

Good, J.M. (2000) 'Disciplining social psychology: a case study of boundary relations in the history of human sciences', Journal of the History of the Behavioral Sciences, 36(4): 383-403.

Kalampalikis, N. and Buschini, F. (2002) 'The Prospero software program: An alternative tool for the study of social representations', European Review of Applied Psychology 52(3-4): 241-251.

Koyré, A. (1961) La révolution astronomique: Copernic, Kepler, Borelli The astronomical revolution: Copernicus, Kepler, Borelli]. Paris: Hermann.

Lewin, K. (1945) 'Research program of group dynamics. The Research Center for Group Dynamics at the Massachusetts Institute of Technology', Sociometry VIII(2): 126-136.

Lubek, I. (2000) 'Understanding and using the history of social psychology', Journal of the History of the Behavioral Sciences, 36(4): 319-328.

Lubek, I. and Apfelbaum, E. (2000) 'A critical gaze and wistful glance at Handbook histories of social psychology: did the successive accounts by Gordon Allport and successors historiographically succeed?', Journal of the History of the Behavioral Sciences, 36(4): 319-328.

Nora, P. (1998) Realms of Memory: The Construction of the French Past. New York and Chichester, West Sussex: Columbia University Press.

Pétard, J.-P., Kalampalikis, N. and Delouvée, S. (2001) 'Les histoires de la psychologie sociale dans ses manuels' [The histories of social psychology into its own textbooks], Les Cabiers Internationaux de Psychologie Sociale 52: 59-80. 


\section{APPENDIX}

List of 26 social psychology textbooks used (by year of publication)

[1954a] Heuse, G. (1954) Eléments de psychologie sociale générale. Paris, Vrin.

[1954b] Sprott, W.J.H. (1954[1952]) Psychologie sociale. Paris, Payot.

[1957] Klineberg, O. (1957) Psychologie sociale, tome 1. Paris, Presses Universitaires de France.

[1963a] Daval, R., Bourricaud, F., Delamotte, Y. et Doron, R. (1963) Traité de psychologie sociale, tome 1. Paris, Presses Universitaires de France.

[1963b] Stoetzel, J. (1963) La psychologie sociale. Paris, Flammarion.

[1967] Zajonc, R.B. (1967) Psychologie sociale expérimentale. Paris, Dunod.

[1968] Prévost, C. et Rocheblave-Spenlé, A.-M. (1968) Leçons de psychologie générale et sociale. Paris, Baillière et Fils.

[1973] Maisonneuve, J. (1973) Introduction à la psychosociologie. Paris, Presses Universitaires de France.

[1974] Castellan, Y. (1974) Initiation à la psychologie sociale. Paris, Armand Colin.

[1976] Albouy, S. (1976) Eléments de sociologie et de psychologie sociale. Toulouse, Privat.

[1977] Badin, P. (1977) Aspects psychosociaux de la vie collective (volume 2) La psychologie de la vie sociale. Paris, Editions du Centurion.

[1979] Bégin, G. et Joshi, P. (1979) Psychologie sociale. Québec, Presses de l’Université Laval.

[1980] Basagana, R. (1980) Eléments de psychologie sociale. Alger, Office des publications universitaires.

[1984] Gergen, K. et Gergen, M. (1984) Psychologie sociale. Laval, Etudes Vivantes.

[1986] Andrééva, G. (1986) Psychologie sociale. Moscou, Editions du Progrès.

[1987] Fischer, G.-N. (1987) Les concepts fondamentaux de la psychologie sociale. Paris, Bordas.

[1993] Maisonneuve, J. (1993) La psychologie sociale. Paris, Presses Universitaires de France.

[1994] Vallerand, R.-J. (éd.) (1994) Les fondements de la psychologie sociale. Boucherville, Québec, Gaètan Morin.

[1996a] Gosling, P. (éd.) (1996) Psychologie sociale. Rosny-sous-Bois, Bréal.

[1996b] Tapia, C. (éd.) (1996) Introduction à la psychologie sociale. Paris, Editions d'Organisation.

[1997] Fischer, G.-N. (1997) La psychologie sociale. Paris, Seuil.

[1998] Cazals-Ferré, M.-P. et Rossi, P. (1998) Eléments de psychologie sociale. Paris, Armand Colin.

[1999a] Bédard, L., Déziel, J. et Lamarche, L. (1999) Introduction à la psychologie sociale. Saint-Laurent (Québec), Editions du Renouveau Pédagogique Inc.

[1999b] Cerclé, A. et Somat, A. (1999) Manuel de psychologie sociale. Paris, Dunod.

[1999c] Pétard, J.-P. (éd.) (1999) Psychologie sociale. Rosny-sous-Bois, Bréal.

[2000] Roussiau, N. (éd.) (2000) Psychologie sociale. Paris, In Press. 


\section{NOTES}

${ }^{1}$ One can add here the filmography devoted to documenting scientific discoveries, which often feeds our memories.

2 In our work the term 'space' is both used in a geographical sense (continents, countries, cities), but also symbolically (network of researchers, institutions, intellectual figures) in reference, in particular, to the works on collective memory by the historian Pierre Nora (1998).

${ }^{3}$ This subtle difference in names for the discipline sometimes hides various schools of thought, notably within the history of European social psychology.

${ }^{4}$ This choice (1946 rather than 1945 or 1947) is strictly metrical. It allows periods to be divided by equal duration.

5 Prospero is a discourse analysis software which allowed us to create collections of 'Authors', 'Cities', and even 'Institutions' which gather, in the taxonomic way of the natural sciences, all the scholars, cities, and institutions cited in our corpus (cf. Chateauraynaud, 2003; Kalampalikis and Buschini, 2002).

${ }^{6}$ In our sample, scholars do not often use the names 'America' $(n=24)$ and 'Europe' $(n=44)$. For America, they mainly use 'United States' ( $\mathrm{n}=111)$, while for Europe, references are shared among France $(\mathrm{n}=70)$, Germany $(\mathrm{n}=32)$ and England $(\mathrm{n}=17)$. We should also remember that the majority of our authors are of European origin.

7 That is, 'America' ( $\mathrm{n}=24)$, or again 'United States' ( $\mathrm{n}=111)$, 'North America' ( $\mathrm{n}=9)$, 'USA' ( $\mathrm{n}=1$ ) and 'Canada' $(\mathrm{n}=10)$.

${ }^{8}$ Dates in brackets refer to the publication dates of the social psychology textbooks analysed and presented in Appendix.

9 Good's historical analysis (2000) moderates this opposition by exposing many elements that show the existence, as early as the nineteen twenties, of the two trends in social psychology in the United States, and of the discussions and exchanges between them.

${ }^{10}$ Names from the list in decreasing order: G. Tarde, W. McDougall, K. Lewin, E. Durkheim, G. Le Bon, G.H. Mead, F.H. Allport, Plato, E. Ross, S. Moscovici.

${ }^{11}$ In decreasing order: G. Tarde, K. Lewin, E. Durkheim, W. McDougall, G. Le Bon, A. Comte, S. Moscovici, F.H. Allport, S. Freud, L. Festinger.

12 One of the chapters [1957] in the sample did not mention any country either.

${ }^{13}$ Typicality means that a city is mentioned in more than $25 \%$ of the sample.

${ }^{14}$ We have not integrated bibliographical references into our analysis, which are presented in a separate manner at the end of chapters.

${ }^{15}$ For example: the European Association of Social Psychology, the Fondation française pour l'étude des problèmes humains, the Société française de psychologie or even UNESCO.

16 What's more, the expression 'in 1945-1947' seems strange. The first edition date is actually 1944 and 1947 corresponds to the date of the second edition.

${ }^{17}$ Remember that these authors, to be considered as 'typical', had to be mentioned in at least one quarter of the 26 textbooks with a number of occurrences equal to or greater than 7. Forty-six names were found 'typical' according to this criteria.

${ }^{18}$ These are, for the second half of the 19th century, Wundt, Mead G.H., then, from 1900 to 1950, Adorno, Moreno, Thurstone, Mayo, Heider, Sherif, Freud, Ross, Allport F.H., Lewin, McDougall and, lastly, from 1950 to 2000 , Stoetzel, Moscovici, Bruner.

${ }^{19}$ For the first period, Tarde, Durkheim, Le Bon, Baldwin, Triplett ; for the second, Asch, Mead M., Allport G.W., Benedict, Cooley, Kardiner, Lévy-Bruhl, Znaniecki, Linton, Newcomb, Murphy, Thorndike, for the third, and last, Gergen, Festinger, Doise and Milgram.

${ }^{20}$ Sometimes one sees 'University of Columbia', 'University of Stanford' instead of Columbia University, Stanford University...approximations translating the confusion between the (supposed) name of the place and the university establishment. 